
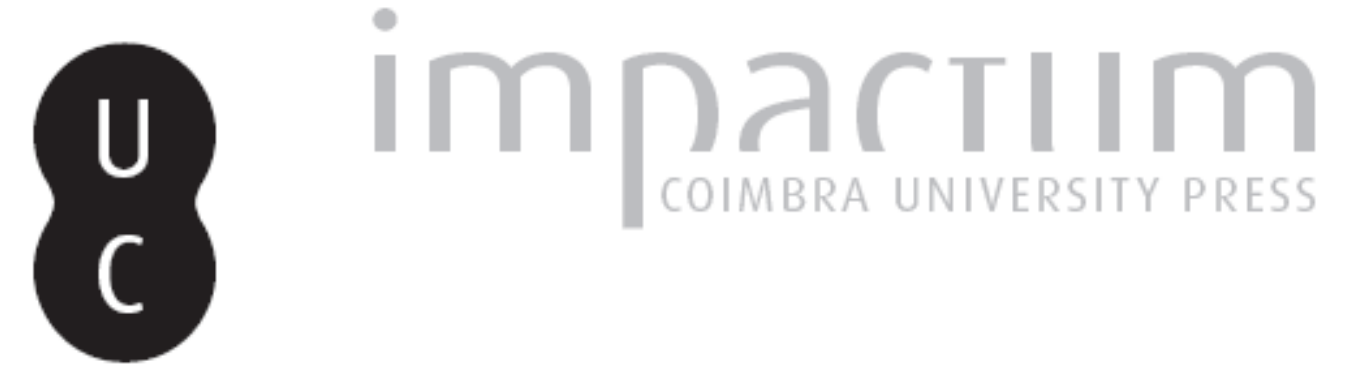

\author{
Riscos naturais e sociedade: estudo de caso no concelho de Braga \\ Autor(es): Teles, Virgínia \\ Publicado por: Associação Portuguesa de Riscos, Prevenção e Segurança \\ URL \\ persistente: \\ URI:http://hdl.handle.net/10316.2/40102 \\ DOI: \\ DOl:https://doi.org/10.14195/1647-7723_8_7 \\ Accessed : $\quad$ 26-Apr-2023 15:55:00
}

A navegação consulta e descarregamento dos títulos inseridos nas Bibliotecas Digitais UC Digitalis, UC Pombalina e UC Impactum, pressupõem a aceitação plena e sem reservas dos Termos e Condições de Uso destas Bibliotecas Digitais, disponíveis em https://digitalis.uc.pt/pt-pt/termos.

Conforme exposto nos referidos Termos e Condições de Uso, o descarregamento de títulos de acesso restrito requer uma licença válida de autorização devendo o utilizador aceder ao(s) documento(s) a partir de um endereço de IP da instituição detentora da supramencionada licença.

Ao utilizador é apenas permitido o descarregamento para uso pessoal, pelo que o emprego do(s) título(s) descarregado(s) para outro fim, designadamente comercial, carece de autorização do respetivo autor ou editor da obra.

Na medida em que todas as obras da UC Digitalis se encontram protegidas pelo Código do Direito de Autor e Direitos Conexos e demais legislação aplicável, toda a cópia, parcial ou total, deste documento, nos casos em que é legalmente admitida, deverá conter ou fazer-se acompanhar por este aviso.

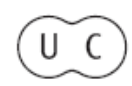




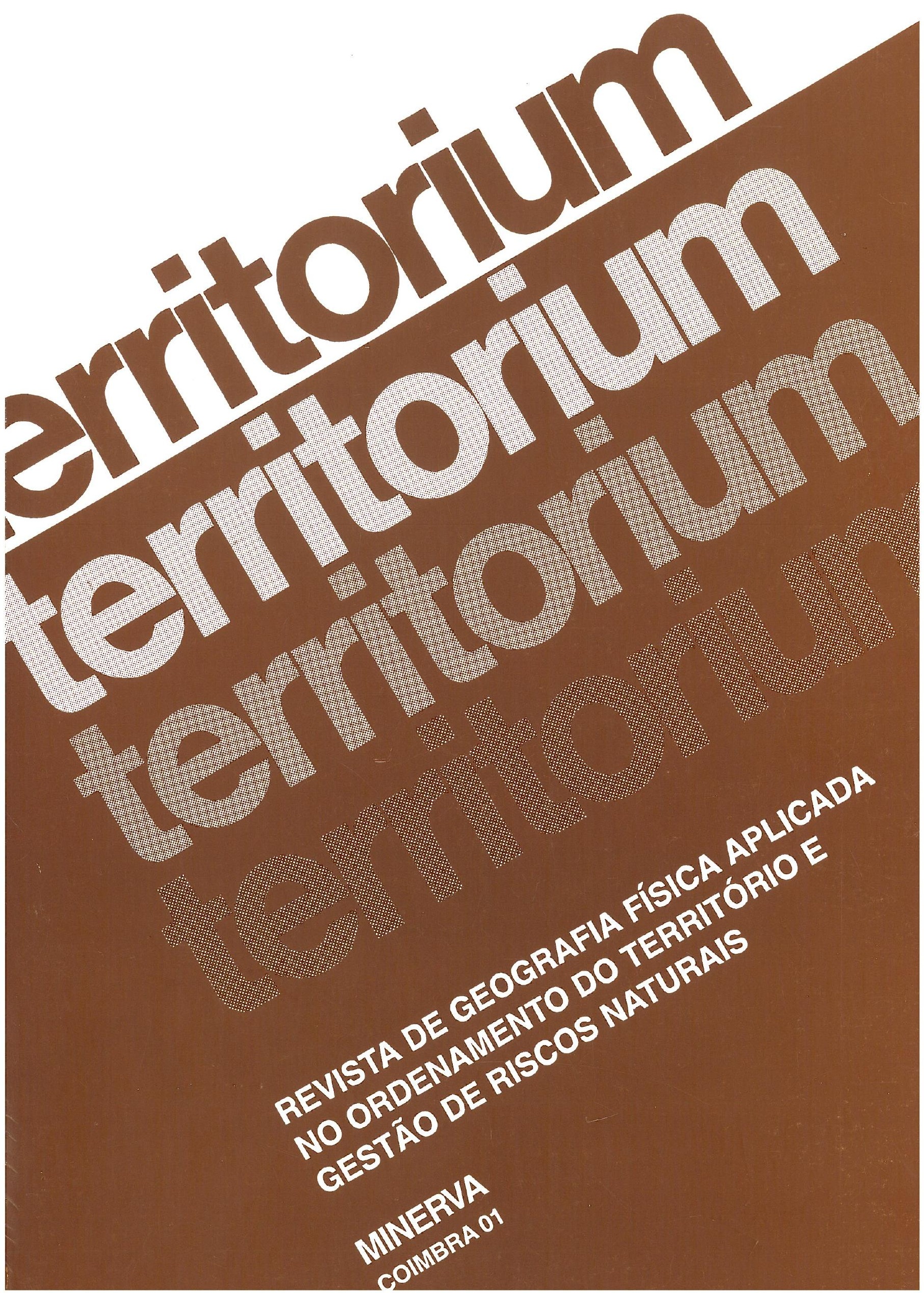




\title{
Riscos Naturais e Sociedade Estudo de caso no concelho de Braga
}

\author{
Virginia Teles*
}

\begin{abstract}
Resumo:
As ameaças com que nos deparamos na sociedade actual levam-nos a equacionar a segurança, também em termos ambientais. A novas ameaças associam-se novos riscos, novas inquietações e medos e é neste contexto que, através da realização de um inquérito a alguns habitantes do concelho de Braga, se pretendeu avaliar o nível de conhecimento que as populações têm do risco e, em particular, qual a stia percepção acerca dos riscos naturais. Para a maioria dos inquiridos, o caso de Lamaçães, que consideraram paradigmático em termos de desordenamento urbano, resultou num bom exemplo de que a definição de estratégias de desenvolvimento para o concelho de Braga deve contemplar a temática dos riscos naturais.

Palavras chave:
\end{abstract}

Segurança ambiental, percepção, riscos naturais, urbanismo desenfreado, (des)ordenamento do território.

\section{Résumé:}

Les menaces que nous faisons face dans la société actuelle nous mènent à considérer la sécurité, aussi, au niveau environnementale. De nouveaux risques, de nouvelles inquiétudes et angoisses ont résulté de ces nouvelles menaces. Et c'est dans ce contexte que nous avons voulu évaluer, par une enquête faite à quelques habitants de la commune de Braga, le niveau de conscience du risque, et en particulier la perception des risques naturelles.

Pour la majorité des personnes questionnées, le cas de Lamaçães, consideré comme un bon exemple de désaménagement urbanistique, traduit un cas exemplaire comme la définition de stratégies pour le développement dans la commune de Braga doit considérer la thématique des risques naturels.

Mots clés:

Sécurité environnementale, perception, risques naturels, urbanisme rapide, (dés)aménagement du territoire.

\begin{abstract}
:
The growing threats that face nowadays society lead us to look at safety also by its environmental point of view. To the new threats, we connect new risks, fears and anguishes. It's upon this context that, after enquiring a Braga County population sample, one has aimed to evaluate the risk assessment ievel, and particularly the natural risk perception level of these people.

For most of the people enquired, the Lamaçães case, has resulted in a fairly good example in as the definitions of development strategies for Braga county should also take into consideration the natural risk assessment issue.

Key Words:

Environmental security, perception, natural hazards and risks, rapid urbanization, (non)management.
\end{abstract}

\section{Introdução}

Se, no passado, a fome, as guerras, as epidemias e a falta de higiene comprometeram gravemente a esperança de vida dos nossos antepassados, desde esses longínquos tempos para cá, a natureza dos riscos mudou substancialmente. O crescimento demográfico, a industrialização, a urbanização e os desequilíbrios sócio-económicos contribuíram para alterar significativamente o domínio dos riscos, sendo hoje frequentes as preocupações com os riscos naturais, os riscos tecnológicos, os riscos económicos e sociais e os riscos biológicos.

\footnotetext{
* Assistente. Secção de Geografia, Instituto de Ciências Sociais, Universi-
} dade do Minho.
Orisco entendido como a probabilidade de ocorrência de fenómenos susceptíveis de causar danos aos homens ou aos seus bens, num determinado tempo e num dado território é uma noção que, embora recente no vocabulário das ciências do ambiente, vem adquirindo particular relevância nas sociedades actuais.

Na interacção entre sociedade, tecnologia e ambiente definem-se os riscos tecnológicos e os riscos naturais principais responsáveis pelos desastres ditos ecológicos ou ambientais cuja frequência tem vindo a aumentar, especialmente a partir de 1976, com o consequente aumento da vulnerabilidade em várias áreas do Globo. A importância atribuída ao incremento do número de acidentes, a partir desta data, poderá estar associado à influência mediática que o acidente de Seveso teve 
na opinião pública. Este exemplo, a par do acidente nuclear de Chernobyl ao provar que a poluição não se confina à delimitação fronteiriça de um país são bons indicadores de como a divulgação e a sua exacerbação podem levar a uma mudança de atitude face ao risco, ou seja, mudar a forma como o risco é percebido. Terá, então, aumentado o número de acidentes graves ou, apenas, a sua percepção resultado de uma maior divulgação, pelos media e pela comunidade científica?

A mera menção de nomes como Bhopal, Chernobyl ou Seveso (ver Quadro I) transmitem-nos imagens de destruição e morte, cenários de estragos ambientais irreversíveis.

Se adicionarmos a estes "monumentos da toxicidade", como são definidos por S. CUTTER (1993), outros nomes como Amoco-Cadiz (Março de 1978), Exxon Valdez (24 de Março de 1989) ou Erika (12 de Dezembro de 1999), que nos trazem à memória derrames de petróleo cada vez mais dramáticos, é evidente que as falhas no sistema tecnológico provocam bastantes danos materiais e pessoais e degradam, irremediavelmente, o ambiente. A problemática do esgotamento dos recursos, a degradação ambiental, as mudanças climáticas e o aumento significativo das catástrofes naturais são, entre outros, factores desencadeadores de inquietação nas populações e alimentam os debates públicos em torno das questões ligadas ao ambiente.

As catástrofes naturais, embora menos temidas, são aquelas que matam mais pessoas. Para termos uma ideia dos danos e dos custos associados a estes

Quadro I

Acidentes Químicos Industriais

\begin{tabular}{|c|c|c|c|}
\hline Seveso & Itália & Jul. 1976 & $\begin{array}{l}\text { Nuvem de produtos químicos com forte teor de } \\
\text { dioxinas (mais de } 500 \text { casos com queinaduras } \\
\text { graves) }\end{array}$ \\
\hline Los Alfaques & Espanha & 1978 & $\begin{array}{l}\text { Fuga de propileno liquefeito após acidente de } \\
\text { camião cisterna, perto de um parque de } \\
\text { campismo - cerca de } 100 \text { mortos }\end{array}$ \\
\hline & México & Nov. 1984 & $\begin{array}{l}\text { Explosão de um complexo petrolífero provoca a } \\
\text { morte de } 450 \text { pessoas }\end{array}$ \\
\hline Bhopal & Índia & Dez. 1984 & $\begin{array}{l}\text { Nuvem de metil isocianeto provoca } 2500 \\
\text { mortes (detém o record do } n^{\circ} \text { de vítimas) }\end{array}$ \\
\hline Chernobyl & Ucrânia & 25 Abr. 1986 & $\begin{array}{l}\text { Explosão de central nuclear (pior acidente } \\
\text { nuclear da história) }\end{array}$ \\
\hline Guadalajara & México & 1992 & $\begin{array}{l}\text { Explosão de hexano mata } 180 \text { pessoas e causa } \\
\text { danos em mais } 600\end{array}$ \\
\hline
\end{tabular}

Fonte: Adaptado do J. DENIS-LEMPEREUR (2000) e S. CUTTER (1993)

Quadro II

Catástrofes Naturais na América Latina e Caraíbas de 1970 a 1999, com mais de 5000 mortes.

\begin{tabular}{|c|l|l|r|r|r|}
\hline Ano & \multicolumn{1}{|c|}{ Pais } & \multicolumn{1}{|c|}{ Tipo } & Mortes & $\begin{array}{c}\text { Pessoas } \\
\text { Afectadas }\end{array}$ & $\begin{array}{c}\text { Custos } \\
\text { (US\$) }\end{array}$ \\
\hline 1970 & Perú & Tremor de Terra & 66794 & 3216240 & 2224966 \\
\hline 1972 & Nicarágua & Tremor de Terra & 10000 & 720000 & 3293672 \\
\hline 1976 & Guatemala & Tremor de terra & 23000 & 4993000 & 2864024 \\
\hline 1985 & Colombia & Erupção Vulcânica & 21800 & 12700 & 1514954 \\
\hline 1985 & México & Tremor de terra & 8776 & 130204 & 6059815 \\
\hline 1998 & $\begin{array}{l}\text { Honduras/ } \\
\text { Nicarágua }\end{array}$ & Furacão MITCH & 8104 & 2980228 & 3000000 \\
\hline 1999 & Venezuela & $\begin{array}{l}\text { Inundações/ } \\
\text { Escoadas de lamas }\end{array}$ & 30000 & 483635 & 1957187 \\
\hline
\end{tabular}

Fonte: CRED/OFDA, EM-DAT, "Base de donnés internationale sur les catastrophes naturelles", 1990-1999 in C. CHARVÉRIAT $(2000$, p. 88$)$ 
acontecimentos catastróficos veja-se o Quadro II onde estão enumeradas algumas das mais graves catástrofes naturais que assolaram a região da América Latina e Caraíbas, ao longo dos últimos 20 anos. Se alargarmos o campo de visão à escala mundial, o cenário é alarmante, constatando-se um aumento exponencial dos acidentes com origem em fenómenos naturais. Relembremos, apenas, alguns dos mais mediatizados no ano de 2000: as inundações em Moçambique e na Europa Central, particularmente em França e na Alemanha, os sismos na Grécia e Turquia e já em Janeiro de 2001 um intenso sismo em El Salvador e outro na Índia. Em Portugal, os últimos meses de Outono e Inverno foram excepcionalmente chuvosos, com fortes precipitações durante vários dias, o que se traduziu num aumento dos caudais levando a situações de cheia nos principais rios e, também, em movimentações de terras, tendo ocorrido desabamentos e deslizamentos um pouco por todo o país (ex: Frades, Arcos de Valdevez, Ariz, etc.).

As catástrofes naturais representam uma verdadeira ameaça para o desenvolvimento dos países, pois, ao afectarem/modificarem o território e a própria população, terão a médio-longo prazo(s), consequências sociais, económicas, e mesmo políticas, de uma gravidade mais ou menos variável. Entre outras, os governantes verão limitada a capacidade de gestão dos recursos do seu território, ao passo que as populações verão aumentada a sua vulnerabilidade, podendo instalar-se no seu seio estados de alguma insegurança.

Desde logo, uma nova abordagem deverá ser contemplada na problematização das questões ambientais - a da segurança, mesmo que seja no seu sentido mais clássico: o de ameaça ao Estado. A segurança dos países foi, até aos anos 70 , entendida exclusivamente em termos de ameaças militares, todavia, é-nos agora fácil perceber que a segurança de um determinado território pode ser comprometida por ameaças de outro tipo: económicas, sociais, biotecnológicas e ecológicas ou ambientais, conforme consta no seguinte quadro.

É neste cenário de novas ameaças que emerge um novo conceito: o de segurança ambiental. Para Paul PAINCHAUD (2000, p. 62) esta noção não se encontra ainda clarificada já que, sendo uma noção bem conhecida da comunidade científica, está impregnada de influências sociais, políticas e normativas que tornam difícil e, por vezes, contraditória, a sua gestão. A título de exemplo: $1^{\circ}$ ) Aquilo que pode parecer um alargamento de consciência ambiental pode ser, apenas, um fenómeno mediático, de oportunidade política ou comercial; $2^{\circ}$ ) Não basta à comunidade científica decretar que esta ou aquela ameaça ambiental é eminente ou grave para que ela se constitua como elemento de política de segurança ambiental de um país; $3^{\circ}$ ) A mesma ameaça pode ser interpretada de maneira diferente pelos diversos governos e a sua apreciação poderá evoluir no tempo em função de factores, igualmente variados como os conhecimentos científicos, a ideologia dominante, a opinião pública ou a capacidade de atenção dos burocratas e das equipas dirigentes.

Indicam-se dois exemplos portugueses bem conhecidos e sintomáticos da relatividade da reacção em termos de segurança ambiental: o da escolha do local para a implantação de um sistema de co-incineração (Alhandra, Maceira, Outão e Souselas) e o caso da "Doença das Vacas Loucas". Enquanto uns se mostram indiferentes aos problemas ambientais, outros consideram-nos como uma ameaça importante à sua segurança, manifestando a seu descontentamento em praça pública, no primeiro caso, ou levantando embargando a importação de carne bovina inglesa e portuguesa, como o fizeram os franceses, no segundo caso. Resulta, assim, uma variedade de percepções de segurança ambiental que aumentará, seguramente, com os conhecimentos científicos e com a rapidez com que flui a informação ambiental.

\section{Quadro III}

Novos factores de insegurança no mundo

- a globalização com as suas interdependências económicas;

- as disparidades regionais com os movimentos migratórios que originam a nível mundial;

- a desintegração de certos regimes políticos e a multiplicação de Estados com delimitação ainda incert. no sistema internacional;

- a propagação de doenças como a SIDA;

- os organismos geneticamente modificados;

- a diminuição da camada de ozono;

- a desflorestação;

- a desertificação;

- o desaparecimento de espécies animais e vegetais raras;

- (...)

Fonte: Adaptado de P. PAINCHAUD (2000, p. 62) 
Vários estudos indicam que o cidadão comum considera os riscos com fraca probabilidade de ocorrê cia, mas com maior gravidade, mais importantes do que aqueles em que a probabilidade de ocorrência é forte mas são limitadas as suas consequências (ver Fig. 1). Indicam, também, que quanto maior é a exposição ao risco por parte das populações, maior é a tendência para se desvalorizar ou esquecer esse mesmo risco. Devemos, no entanto, reter que, quer eta situação, quer a ausência de percepção do risco, tornam as pessoas mais vulneráveis face a esses riscos.

\section{Percepção dos riscos}

É nosso propósito, com este trabalho, tentar avaliar a consciência da exposição ao risco por parte de um grupo de cidadãos do concelho de Braga. Avaliar, como referem M. L. LIMA e L. M. FAÍSCA (1992, p. 13), o "limiar da consciência" que, para os autores, marca a passagem do estádio da ignorância do risco para o seu conhecimento, ou seja, para a identificação do perigo. O passo seguinte é o da inventariação que mais não é que a detecção dos riscos/perigos que

Fig. 1 - O Espaço do Perigo (seg. G-Y. KERVERN;

P. RUBISE, 1991, p. 24).
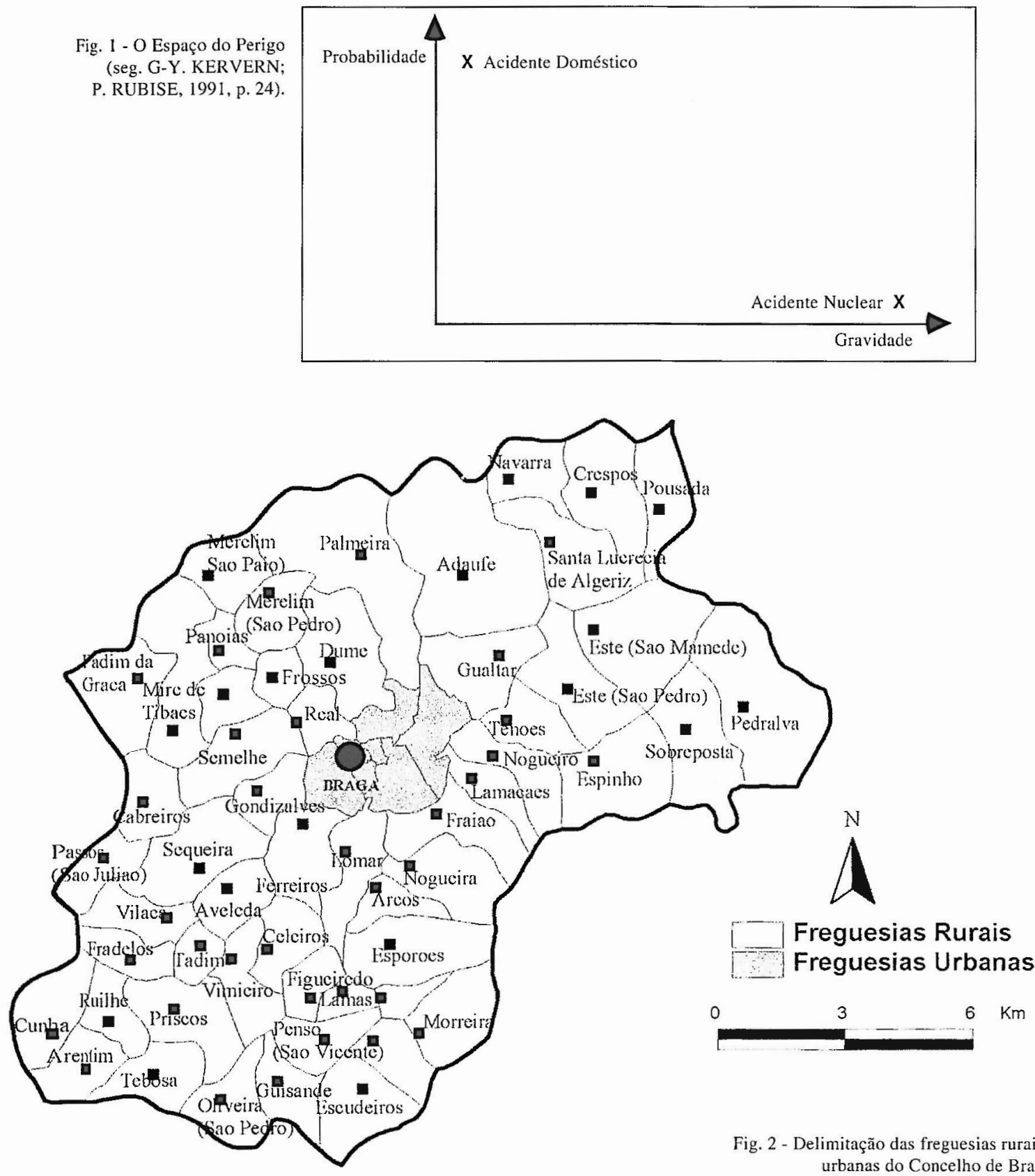

Fig. 2 - Delimitação das freguesias rurais e urbanas do Concelho de Braga. 
afligem as pessoas, no fundo, quais os seus medos e as suas inquietações.

Realizámos, então, um inquérito por questionário a 200 habitantes, maiores de 15 anos, residentes 127 deles em freguesias rurais e os restantes $73 \mathrm{em}$ freguesias urbanas do concelho de Braga (Fig. 2) com o propósito de responder a duas questões fundamentais: i) Qual o nível de conhecimento do risco? e ii) De que modo são percepcionados os riscos naturais?

Com este inquérito pretende-se saber o que pensam estes habitantes sobre a problemática dos riscos naturais. Sabendo tratar-se de um assunto pouco divulgado, orientámos, de forma consciente, as questões no sentido de permitir uma melhor compreensão deste assunto. Iniciámos o questionário com uma questão abrangente, de enquadramento das interacções entre acção humana, natureza e ambiente, sendo a introdução à temática dos riscos naturais feita pela indicação de termos como: risco, perigo, acidente, desastre e catástrofe, para os quais se pedia um significado. A averiguação das inquietações, dos medos e das preocupações fundamentais para os cidadãos em termos sociais, económicos e ambientais, veio a seguir, bem como a exposição aos riscos naturais face à exposição a outros riscos. Aproveitou-se, igualmente, este inquérito para saber que percepção da qualidade do ambiente no seu concelho e na sua freguesia têm estes habitantes e terminámos com uma interrogação acerca da importância da temática dos riscos naturais na agenda política municipal.

A análise dos resultados do inquérito obedeceu ao cruzamento das respostas dadas, às questões formuladas, com as variáveis sexo, idade, grau de instrução, profissão/condição perante o trabalho e, por último, com o local de residência.

Na sua relação com a natureza, o papel do homem foi evoluindo ao longo do tempo, conforme os estádios de desenvolvimento atingido pela própria sociedade: desde um primeiro estádio onde há uma mútua interacção do homem com a natureza ("ecocentrismo"), passando para outro onde o homem, pela acumulação de cultura e da tecnologia, controla e modifica a natureza ("antropocentrismo") até ao estádio onde se põe em causa todo o progresso tecnológico, se pedem responsabilidades por intervenções negativas do homem sobre a natureza, em que a natureza tem que ser preservada.

Comungando da opinião expressa por M. L. LIMA e L. M. FAÍSCA $(1992$, p. 7), ao referirem que a natureza só se torna uma ameaça quando interage com o Homem e que os desastres/catástrofes naturais ilustram uma situação extrema da interacção homemnatureza tentamos, junto dos entrevistados, saber que tipo de relação homem-natureza privilegiam na sociedade actual.
A maioria dos inquiridos aponta o dedo ao papel destruidor do Homem, pois $62 \%$ do total das respostas indicam que a natureza tem que ser preservada. É de resto a opinião dos inquiridos do sexo masculino. Com menor número de respostas, $32 \%$ dos inquiridos consideram que, através da ciência e da técnica, o Homem controla e modifica a natureza e são as mulheres aquelas que mais partilham desta opinião $(35,1 \%)$. A relação harmoniosa entre a natureza e o Homem é considerada, apenas, para um número ínfimo de inquiridos, apenas $2,5 \%$.

Ao analisarmos a distribuição das respostas por classes etárias verificamos que com a idade aumenta o número daqueles que se posicionam a favor da preservação da natureza. Em destaque a classe etária dos mais idosos (com 65 ou mais anos) onde esta opção é a única escolhida, embora haja, aqui, uma grande percentagem de inquiridos que não sabem ou não respondem a esta questão $(11,8 \%)$, o que pode revelar algum desconhecimento deste assunto por parte dos mais velhos. Os mais jovens (dos 15 aos 35 anos) atribuem alguma importância à intervenção dominadora do homem face à natureza, enquanto que o equilíbrio homem-natureza é, apenas, referido por uma pequena percentagem de adultos.

Considerando o grau de ensino, são os inquiridos com um grau de instrução mais baixo os que valorizam a preservação da natureza enquanto que os mais instruídos consideram que o homem domina e controla a natureza.É no ensino básico e no ensino preparatório que vamos enquadrar as respostas a favor de uma relação harmoniosa entre estes dois elementos. Quanto à profissão e condição perante o trabalho, os quadros superiores e os estudantes valorizam o papel do homem enquanto para os restantes é penalizada a intervenção "negativa" do homem sobre a natureza, levando a maioria dos inquiridos a responder a favor da preservação da natureza. De destacar que os agricultores são, exclusivamente, a favor da natureza e é para as domésticas, para os reformados e para uma pequena percentagem de inquiridos do sector do comércio e serviços que a relação homem-natureza se pode considerar harmoniosa. É, ainda, no meio rural que a relação harmoniosa colhe maior número de respostas e é, também, para a maioria dos rurais que a natureza é mais valorizada, com $66,9 \%$ de respostas, enquanto que a importância do papel controlador do Homem tem maior representação na opinião dos urbanos.

"A questão ambiental e a sua percepção em Portugal” (L. CUNHA e R. JACINTO, 1992) foi um trabalho pioneiro no discurso das questões ambientais de então; os resultados apresentados do tratamento dos inquéritos realizados a uma população estudantil foram considerados, na opinião dos autores, preliminares e sumários não permitindo tirar conclusões 
generalizáveis sobre a percepção das questões ambientais para a totalidade do país. Abordando ideias comuns, surgiu um trabalho recente intitulado "Os Portu gueses e o Ambiente", com organização de J. F. ALMEIDA (2000), onde foram apresentados os resultados do I Inquérito Nacional às Representações e Práticas dos Portugueses sobre o Ambiente. No capítulo 1 sobre as representações e valores sobre a natureza e ambiente (p. 7-31) é, entre outras, analisada a relação dos inquiridos com a natureza, levando à individualização de dois grupos: um com indivíduos mais críticos para com a acção humana sobre a natureza e um outro com indivíduos menos críticos. Nas três classes etárias que vão dos 15 aos 49 anos, domina o peso dos mais críticos. Os mais velhos apresentam-se como os mais indefinidos. Com o grau de escolaridade cresce o número dos críticos. Os estudantes e os intelectuais, os quadros superiores e dos serviços revelam-se os mais críticos enquanto que os menos críticos são os desempregados. Conclui-se que "de facto, a concepção dos inquiridos relativamente à sua relação com a natureza e o ambiente não surge muito marcada por uma representação da natureza enquanto vítima" (ob. cit., p. 31), o mesmo não poderemos afirmar para o grupo que entrevistámos, cujo perfil é o oposto. No nosso caso a intervenção da acção humanaé penalizante sendo, mesmo, considerada para muitos uma verdadeira ameaça.

Se procurarmos o significado de termos como risco, perigo, acidente, desastre ou catástrofe, que fazem parte do léxico das ciências cindínicas, vamos verificar que alguns deles são de difícil definição, mesmo para os membros da comunidade científica que se dedicam a estes assuntos.

Ao analisarmos o significado atribuído pelos nossos entrevistados constatamos uma grande confusão na compreensão dos termos risco e perigo, sendo o risco o de mais difícil definição. Da opinião expressa (ver Fig. 3), o risco tem para grande parte dos entrevistados uma dimensão pessoal, subjectiva, está associado a acontecimentos incertos, no futuro:arriscar. O perigo tem, também, maioritariamente, uma dimensão pessoal, mas revela-se alguma importância da dimensão tecnológica, particularmente, associada a acidentes de viação e à circulação nas estrada, ou seja, a situações que põem em risco pessoas e/ou bens. $\mathrm{O}$ acidente é associado, de forma espontânea, a acidentes de viação (circulação na estrada), mas, também, a acidentes de trabalho, o que lhe atribui uma dimensão tecnológica. Ao desastreestá associada uma maior gravidade, são referidos não só os acidentes rodoviários, mas os acidentes ferroviários e os acidentes aéreos, quase sempre fatais, atribuindo-lhe importante dimensão tecnológica ( $25 \%$ ), todavia é de realçar o peso que a dimensão natural apresenta $(23 \%)$ Os desastres são para muitas pessoas, desastres ecológicos. A catástrofe, acontecimento acompanhado de morte e perdas incalculáveis, é na sua maioria natural.

O risco é inerente à própria vida. Desde o trabalho aos transportes, desde a alimentação à saúde ou mesmo ao lazer, podemos afirmar que o risco faz parte do quotidiano, traduzindo-se num crescente sentimento de inquietação em toda a sociedade.

Para facilitar a análise e comparação dos problemas que mais preocupam os cidadãos no concelho de Braga, a avaliar pelas respostas deste conjunto de entrevistados, definimos cinco grupos onde os medos e as inquietações se agregam por afinidade, embora com dificuldade de enquadramento para alguns deles, em termos de factores naturais, tecnológicos, económicos, sociais ou pessoais. Na dimensão natural contemplam-se os problemas relacionados com fenómenos naturais como: inundações, sismos, vulcões, tremores de terra ou incêndios, mas também os problemas relacionados com as situações extremas ou nefastas da relação homem-natureza, como a degradação e destruição do ambiente, a poluição
Fig. 3 - Os conceitos e as respostas atribuídas pelos inquiridos ao seu significado,

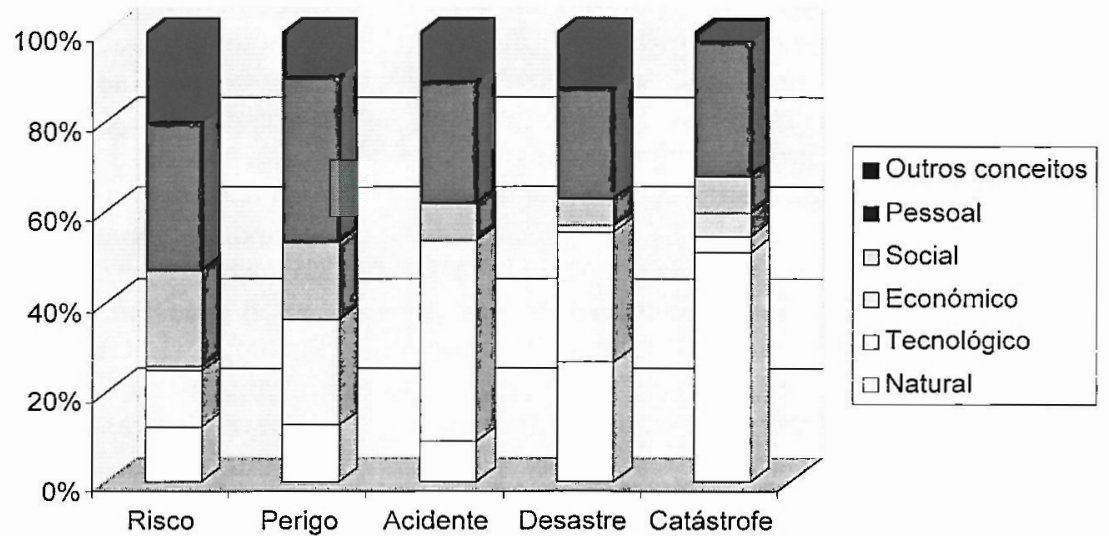


atmosférica, entre outros. A dimensão tecnológica engloba problemas como a contaminação das águas, o ruído, os lixos, a alimentação artificial e, também, desastres nucleares, explosões, acidentes rodoviários e de trabalho. O desemprego, o custo de vida e a pobreza foram inseridos na dimensão económica. A maior diversidade surge na dimensão social que agrega problemas relacionados com a saúde como a sida ou o cancro, com problemas de segurança/insegurança como vandalismo, assaltos, violência, crime, maus tratos, violação, droga, pedofilia, ou outros como o crescimento desordenado das cidades, a destruição do património construído, o civismo. O último grupo corresponde aos problemas do foro íntimo, particulares, como a solidão, o sofrimento, a morte, o futuro, o desconhecido, o insucesso que consideramos de dimensão pessoal.

Quando questionados sobre os riscos ou os perigos a que se encontram expostos, apenas 14 indivíduos respondem não estar sujeitos a nenhum tipo de perigo, para os restantes (ver Fig. 4), as suas principais inquietações estão associadas à exposição crescente aos riscos sociais $(31 \%)$ - no domínio da saúde, à falta de segurança, à violência e aos riscos tecnológicos $(30,8 \%)$, como os acidentes de viação, os atropelamentos e os acidentes de trabalho. Em terceiro lugar, com apenas $16,8 \%$ do total das respostas, surgem as preocupações associadas à exposição aos riscos naturais como a poluição atmosférica, as radiação ultravioletas, o buraco do ozono, os acidentes ecológicos, vulcões, tremores de terra, inundações, entre outros.

Os homens consideram-se mais expostos aos riscos comuma dimensão tecnológica $(33,7 \%)$ enquanto que as mulheres valorizam a dimensão social $(35,6 \%)$, pois referem a violência e os assaltos/roubos como principais preocupações. A dimensão natural, sendo pouco importante para o sexo masculino, tem uma importância significativa para o sexo feminino $(19,3 \%$ das respostas), já que são elas que mais referem a exposição a fenómenos naturais como inundações, tremores de terra e incêndios.

Quanto à idade, são os mais jovens que, embora mais expostos aos riscos sociais, maior importância atribuem aos riscos com uma dimensão natural. Com uma distribuição equitativa por todos os escalões etários, a exposição ao risco tecnológico tem, no entanto, no grupo dos indivíduos com mais de 65 anos o seu valor máximo ( $37,8 \%$ de respostas), facto que se explica pelo receio que estes indivíduos têm de circular na via pública, pois são eles os que mais se referem aos atropelamentos e às velocidades excessivas dos automóveis a circular na cidade. A exposição ao risco social tem na classe etária dos 36 aos 49 anos a sua maior percentagem de respostas $(38,3 \%)$.

São os mais instruídos aqueles que valorizam a exposição ao risco natural enquanto os que apresentam um nível de instrução mais baixo valorizam a dimensão tecnológica, particularmente os riscos relacionados com acidentes de trabalho. A dimensão social é, também, mais referida pelos menos instruídos, assim como é neste grupo de indivíduos que se encontra um número significativo de respostas $\mathrm{ns} / \mathrm{nr}$.

Os indivíduos com profissões pertencentes a quadros superiores e os estudantes atribuem uma grande importância à exposição aos riscos com uma dimensão natural $(29,8 \%$ e $26,1 \%$, respectivamente), referindo-os como segunda opção atrás da dimensão tecnológica $(31,6 \%)$, no primeiro caso e da dimensão social $(30,4 \%)$ no segundo caso. Ao analisarmos a distribuição das respostas pelas condições perante o trabalho verificamos que a dimensão social tem uma distribuição bastante uniforme, embora com valores sensivelmente mais baixos nos inquiridos pertencentes aos quadros superiores e aos quadros intermédios, ambos com $28,1 \%$ de respostas. A dimensão tecnológica, por

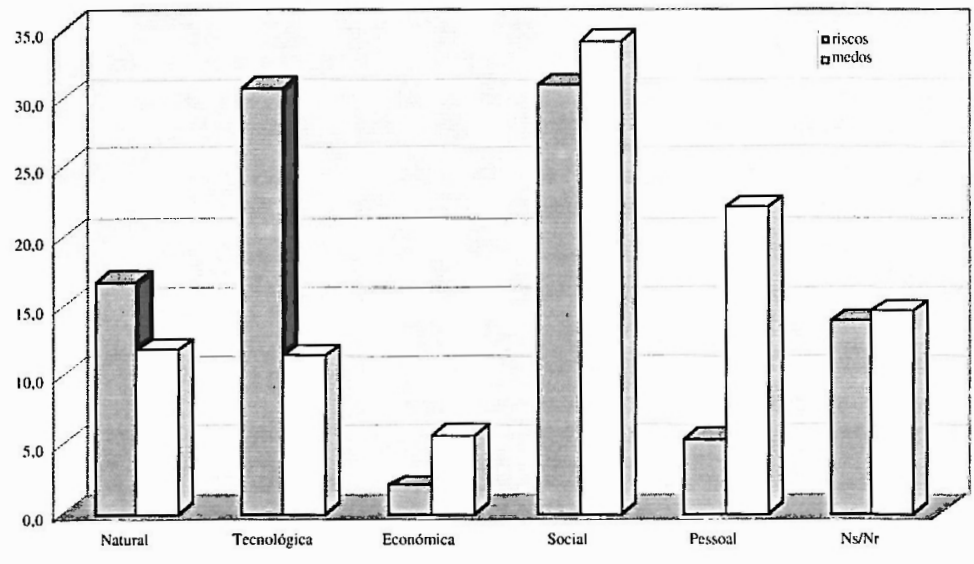

Fig. 4 - A dimensão do medo e dos riscos em função das respostas dos inquiridos. 
sua vez, apenas para os agricultores e para os desempregados tem pouca importância.

$\mathrm{Na}$ oposição meio rural/meio urbano verificamos que a exposição aos riscos sociais ( $36,4 \%$ de respostas) tem grande importância nas freguesias rurais, enquanto que cidade a exposição ao risco tecnológico é mais elevada ( $30,9 \%$ de respostas); devemos recordar que os problemas relacionados com o trânsito, especialmente os acidentes de viação, foram sobremaneira indicados pelos citadinos. Digno de destaque é o segundo lugar alcançado pela dimensão natural $(27,5 \%)$ nas opções dos inquiridos das freguesias urbanas.

Embora, com uma percentagem muito baixa no total das respostas (2\%), a dimensão económica é indicada por uma pequeno número de indivíduos pertencentes ao meio rural, sem saber ler e que se dedicam à agricultura.

A exposição crescente a vários riscos, sejam eles naturais ou não, aumenta o medo nas pessoas e na sociedade. De forma a discernir se a exposição ao risco/perigo éentendida como uma exposição directa, e o medo, como algo mais subjectivo e intangível, perguntamos aos entrevistados: De que tem medo?

O medo, definido no Dicionário de Língua Portuguesa como um "sentimento de inquietação que se sente com a ideia de um perigo real ou aparente" (Porto Editora, 1994), desencadeia em muitos dos entrevistados o mesmo tipo de reacção/ resposta que se verificou na exposição ao risco. É de registar que 18 indivíduos referem não ter medo de nada e $14,7 \%$ de inquiridos não sabem ou não respondem a esta questão. Da opinião expressa, para $34,1 \%$ de indivíduos os medos têm uma componente social, especialmente no domínio da saúde e, em segundo lugar, com $22,2 \%$ surgem os medos associados a uma dimensão mais pessoal; os medos associados à dimensão natural e à dimensão tecnológica acolhem $11,9 \%$ e $11,5 \%$, respectivamente, do total das respostas. Embora a dimensão social seja a mais referida pelos dois sexos, os medos associados ao foro pessoal $(22,8 \%)$ e ao domínio tecnológico são mais importantes para os homens enquanto que para as mulheres os medos são maioritariamente do foro social $(35,6 \%)$ seguido do medo de fenómenos naturais como: inundações, intempéries, vulcões, tempestades....

Ao considerarmos a idade dos entrevistados, verificamos que os medos associados à dimensão social são os mais referidos por todas as classes etárias, com destaque para as classes dos 36 aos 49 anos $(37,3 \%)$ e com mais de 65 anos $(41,7 \%)$, onde os problemas com a saúde assumem particular relevância. Na classe dos mais idosos, os medos associados à dimensão tecnológica são indicados por $19,4 \%$ dos entrevistados, o que não é alheio, comojá fizemos referência anteriormente, aos acidentes de viação e atropelamentos tão citados por estes indivíduos. A dimensão pessoal do medo diminui à medida que a idade avança, tendo nos mais jovens as mais altas percentagens, o que se compreende porque é nos mais jovens que reside o maior grau de incerteza face ao futuro: das suas respostas constatamos que o medo estava associado ao desconhecido, ao futuro, ao sucesso/insucesso e à morte. São, contudo, as classes dos mais jovens (dos 15 aos 23 anos) e dos mais idosos (com mais de 65 anos) onde é maior percentagem de respostas não sabe/não responde.

Os medos associados à dimensão natural, embora pouco referidos, são indicados pelos jovens entre 24 e 35 anos e pelos mais instruídos. Em termos de escolaridade, podemos referir que a dimensão social do medo decresce à medida que o grau de instrução aumenta, enquanto que a dimensão pessoal apresenta uma distribuição relativamente regular. No ensino básico temos a maior dificuldade de resposta a esta questão $(20,4 \%$ de ns/nr).

Segundo a condição perante o trabalho, apenas de referir que os medos têm uma dimensão natural para os quadros superiores $(15,8 \%)$, para os desempregados (16,7\%) e para os estudantes $(19,4 \%)$. São os quadros intermédios e as profissões pertencentes ao sector do comércio e serviços e os reformados que mais referem a dimensão social. A dimensão pessoal é mais para os operários $(26,9 \%)$ e para os desempregados $(33,3 \%)$.

No meio rural os medos e as inquietações das pessoas têm enquadramento nos domínios social (36\%), pessoal $(23,1 \%)$ e, em menor número, no económico (7\%). Os medos com uma componente natural $(16,2 \%)$ e tecnológica $(13,2 \%)$, embora com menor percentagem de respostas, tem nos urbanos maior representação.

\section{Grau de importância atribuída aos vários tipos de riscos}

Foi pedido aos inquiridos que, numa escala de 1 (fraca) a 3 (elevada) atribuíssem um grau de importância aos riscos naturais, aos riscos tecnológicos e aos riscos económico e sociais, para os quais se pedia, igualmente, um exemplo elucidativo(ver Tabela I). No total das respostas e em termos de elevada importância atribuída, os riscos tecnológicos surgem em primeiro plano com $18,5 \%$ de respostas seguidos dos riscos naturais com $15,2 \%$ e por fim os riscos ditos económicos e sociais com $13,0 \%$, que têm para grande parte dos entrevistados $(17 \%)$ um grau de importância média.

Verificamos que os riscos naturais preocupam já os cidadãos, especialmente os do sexo feminino $(17,4 \%)$, os mais jovens entre os 15 e os 35 anos de idade $(17,7 \%$ e $17,3 \%$ respectivamente), os mais 
Tabela I - Tipo de riscos apresentados pelo entrevistador $\left(n^{\circ}\right.$ respostas)

\begin{tabular}{|c|c|c|c|c|c|}
\hline \multicolumn{2}{|l|}{ Naturais } & \multicolumn{2}{|l|}{ Tecnológicos } & \multicolumn{2}{|c|}{ Económicos e Sociais } \\
\hline Sismos & 50 & Poluição & 67 & Custo de vida & 46 \\
\hline Tempestades & 44 & Desastre nuclear & 20 & Desemprego & 37 \\
\hline Inundações/cheias & 36 & Resíduos tóxicos & 17 & Exclusão social & 32 \\
\hline Incêndios & 29 & Acidentes fábrica & 17 & Segurança/violência & 14 \\
\hline Vulcões (actividade vulcânica) & 7 & Camada Ozono/Aquecimento global & 6 & Droga & 10 \\
\hline Desabamentos de terras & 5 & Explosões & 4 & Saúde (sida) & 11 \\
\hline Nevoeiro, Geada, Neve & 3 & Bombas gasolina (junto habitações) & 4 & Endividamento & 9 \\
\hline & & Utilização de adubos químicos & 2 & Guerra & 5 \\
\hline Poluição (ar e rios) & 9 & Alimentação artificial & 1 & Falência & 3 \\
\hline Desastres ecológicos & 2 & Lixeiras & 1 & Bolsa & 2 \\
\hline Buraco Ozono & 1 & Esgotos & 1 & & \\
\hline & & & & Crise económica & 9 \\
\hline & & Desenvolvimento Tecnologia & 11 & Crise social & 6 \\
\hline & & Erro humano & 4 & Poder politico & 1 \\
\hline & & Acidentes traballo. & 2 & Outros & 9 \\
\hline & & Falência & 1 & & \\
\hline
\end{tabular}

instruídos e, também, os indivíduos com profissões pertencentes a quadros superiores $(17,5 \%)$ e graus intermédios $(16,7 \%)$, bem como os estudantes $(20,4 \%)$ e os desempregados $(19,4 \%)$ e aqueles que vivem no meio rural.

Chegados à fase em que se introduziu, directamente, a questão dos riscos naturais no questionário, indicouse uma lista com alguns tipos de riscos naturais como: tremores de terra/sismos; inundações/cheias; ventos fortes/ciclones; movimentos de terras e incêndios florestais para servir de referência às escolhas feitas pelos inquiridos sobre o tipo de riscos naturais que afectam o seu concelho e/ou a sua freguesia.

Da opinião expressa, constatamos que os riscos naturais que mais afectam o concelho de Braga são, destacadíssimos, os incêndios florestais, os ventos fortes e as inundações, tendência repetida quando nos reportamos à freguesia.

Se analisarmos a variável sexo verificamos que não há diferenças significativas, apenas a referir as escolhas a favor dos ventos fortes que, no concelho, são destacados pelos homens $(19,1 \%)$ enquanto que as inundações são destacadas pelas mulheres (19\%), posicionamento que se torna oposto quando se referem aos tipos de risco na freguesia. É ainda ao nível da freguesia que o risco de movimentos de terras é importante para as mulheres. Com a idade verificamos que, tanto para o concelho como para a freguesia, os sismos (neste caso a memória é um bom indicador) e os ventos fortes vão sendo mais referidos, enquanto que para os incêndios florestais e para as inundações se passa o contrário. Os movimentos de terras, por sua vez, têm mais importância para os mais jovens e para a classe dos mais idosos (65 e mais anos).

No que diz respeito ao grau de instrução verifica-se, apenas, que para os incêndios florestais, excepção feita aos inquiridos que não sabem ler $(38,5 \%)$, a importância atribuída a este tipo de risco aumenta com a escolaridade, ou seja, com o conhecimento. Para as profissões associadas a quadros superiores e aos serviços, paraas domésticas e para os reformados, os ventos fortes vêm logo a seguir aos incêndios florestais no ranking dos riscos naturais do seu concelho enquanto que para os quadros intermédios, para os desempregados e para os estudantes, são as inundações que ocupam o segundo lugar. Os riscos naturais que afectam a freguesia são para as profissões pertencentes aos quadros intermédios e aos serviços, para as domésticas e para os reformados, os incêndios florestais. Os quadros superiores atribuem igual percentagem à importância dos incêndios, das inundações e dos ventos fortes.

Os riscos naturais que mais afectam o concelho são, na opinião dos inquiridos que vivem no meio rural, os sismos e os ventos fortes a que se juntam os incêndios florestais quando estes inquiridos se reportam à sua freguesia. Quanto aos inquiridos que vivem nas freguesias urbanas, eles valorizam mais as inundações e os movimentos de terras e especialmente os incêndios florestais no que diz respeito aos riscos para o concelho, quanto aos riscos na freguesia são os que têm mais dúvidas ( $10,7 \%$ de ns/nr), conforme se pode constatar na Fig. 5.

A capacidade de interpretar o meio que nos rodeia é diferente de indivíduo para indivíduo porque são, também, diferentes as suas vivências: o sentido, o vivido e o imaginado tornam a percepção do meio o produto de códigos sensoriais de informações que the chegam de diversos ambientes (culturais, sociais económicos, psicológicos) e que são guardados na memória dos indivíduos, à qual se recorre para formar uma imagem mental, que produzirá um modelo simplificado do real (A. BAILLY, 1977, 1989).

Na tentativa de avaliarmos a percepção do grau de risco a que este grupo de habitantes se encontra exposto, em termos de acidentes naturais, perguntamos 

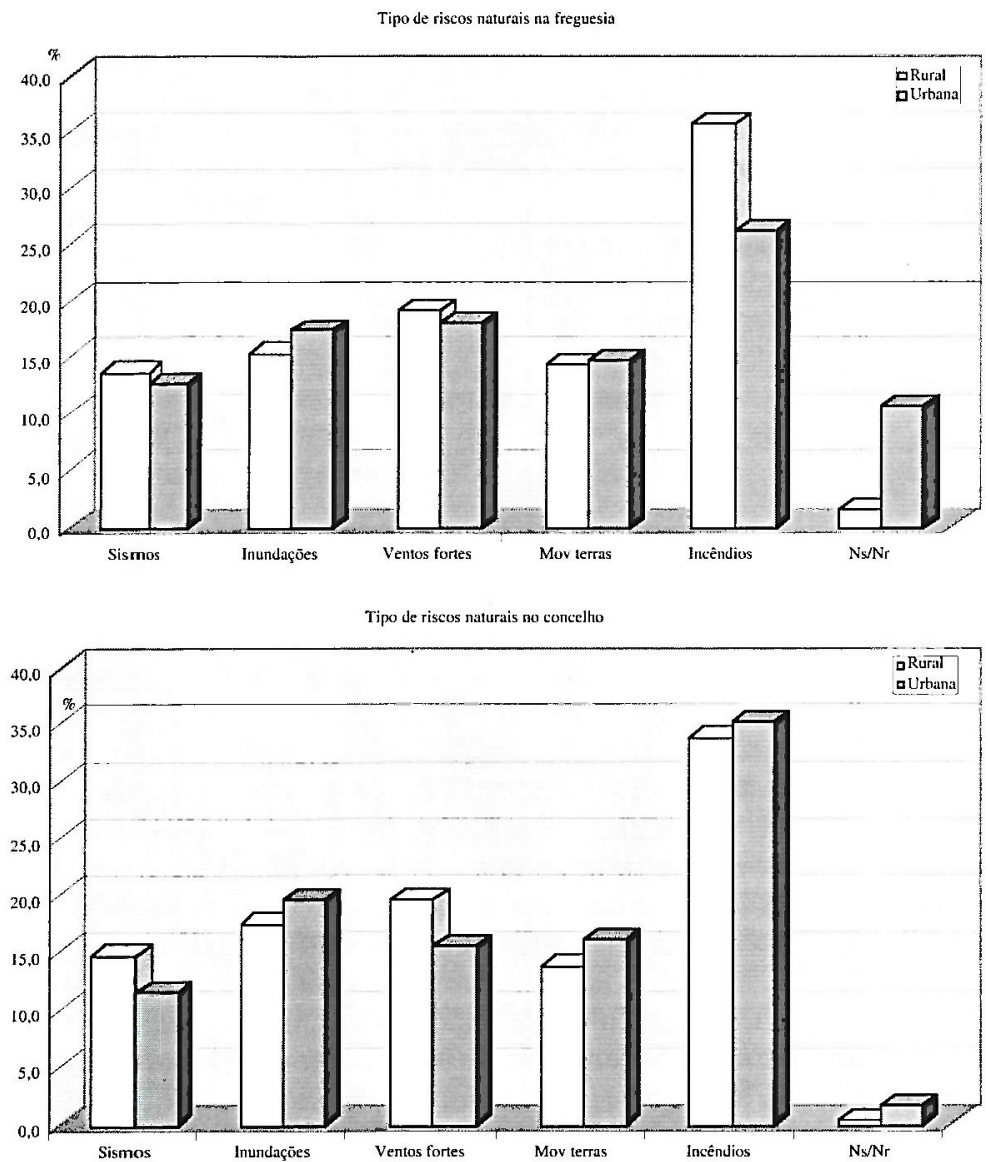

Fig. 5 - Percepção dos riscos naturais no concelho e na freguesia, por local de residência.

numa escala de 1 (muito fraco) a 5 (muito forte) como consideram o risco de acidentes naturais no seu concelho e, também, na sua freguesia o que tornará mais fácil a resposta, pois trata-se de uma realidade bem conhecida.

No total das respostas, o risco de acidentes naturais é considerado médio para o concelho e médio/fraco para a freguesia. Quanto ao sexo, os homens consideram que o risco é médio $(52,8 \%)$ no concelho e que tem tendência a diminuir na sua freguesia, as mulheres, por sua vez, são as que mais consideram fraco o risco de acidentes naturais no concelho e na freguesia, não obstante é igualmente o sexo feminino aquele que já refere a possibilidade de ocorrência de riscos fortes tanto no concelho (14,9\%) como na freguesia (16\%).

Para todas as classes etárias, em especial para a dos mais jovens, o risco é considerado médio no concelho, dos 24 aos 35 anos e dos 50 aos 64 anos considera-se o risco fraco e são os mais idosos que dizem que o risco de acidentes naturais no concelho é forte. Ao nível da freguesia, todas as classes etárias consideram o risco médio/fraco, sendo de destacar a classe dos 15 aos 23 anos que indica uma percentagem de 20,3 a favor de um risco forte e a classe dos 36 aos 49 anos onde em terceiro lugar com $10,7 \%$ de respostas surge um risco muito forte para a freguesia.

Quanto ao grau de instrução, apenas uma referência para os indivíduos com o ensino superior que contrariam a tendência de grau de risco médio a fraco para o concelho, indicando que essa tendência é antes media $(41,7 \%)$ a forte $(25,0 \%)$. Na freguesia a tendência tende a ser média a fraca, mas com valores superiores da percepção fraca comparativamente ao concelho. Destaque para os indivíduos que não sabem ler, embora poucos no total, consideram que a tendência é média a forte. No ensino superior há a particularidade de ser a percepção do risco fraca a que apresenta maior percentagem de respostas $(37,5 \%)$, todavia a percepção de risco forte é aqui bastante considerável, com $20,8 \%$.

A percepção dos riscos naturais no concelho é para os desempregados e para os reformados, tendencialmente média a forte, enquanto que para as domésticas essa percepção é fraca $(66,7 \%)$. Quando nos referimos à percepção dos riscos naturais na freguesia, as opiniões são no sentido de um risco fraco, excepção 
feita aos agricultores para os quais o risco ou é médio ou muito forte e para os estudantes e os reformados que consideram médio o risco de acidentes naturais na sua freguesia.

Podemos afirmar, ainda, que o risco natural no concelho e na freguesia é considerado médio para os entrevistados que vivem no meio rural e médio a fraco para aqueles que vivem na cidade.

\section{A percepção da qualidade ambiental}

A introdução de uma questão sobre a qualidade do ambiente serviu, à semelhança de que fizemos em trabalho anterior sobre a escolha de locais de implantação de edifícios escolares (V. TELES, 2001), para verificar até que ponto as pessoas estão sensibilizadas para a problemática ambiental e, desta forma, sentir se conceitos como degradação ambiental e qualidade do ambiente se entrecruzam com os de bem-estar e qualidade de vida nas cidades.

A qualidade do ambiente foi "medida" numa escala de muito má (1) a muito boa (5). Para o concelho, a qualidade do ambiente é no total das resposta considerada razoável $(46,0 \%)$ a má $(27,5 \%)$, apenas $12,5 \%$ dos inquiridos referem que a qualidade é boa. Os homens partilham desta opinião geral, no entanto, as mulheres revelam-se mais críticas indicando que a qualidade do ambiente no concelho é razoável $(47,9 \%)$ - má $(26,6 \%)$ - muito má $(11,7 \%)$. São os idosos que maioritariamente referem a qualidade do ambiente como razoável, os indivíduos entre os $24 \mathrm{e}$ os 35 anos, por sua vez, consideram esta qualidade má. É nos mais jovens, até aos 23 anos, que vamos encontrar menores valores para o ambiente mau $(20,3 \%)$ e maiores valores para um ambiente bom $(17,2 \%)$.

Quanto ao grau de instrução, o destaque vai para os inquiridos com oensino superior pois estes contrariamente aos restantes consideram a qualidade do

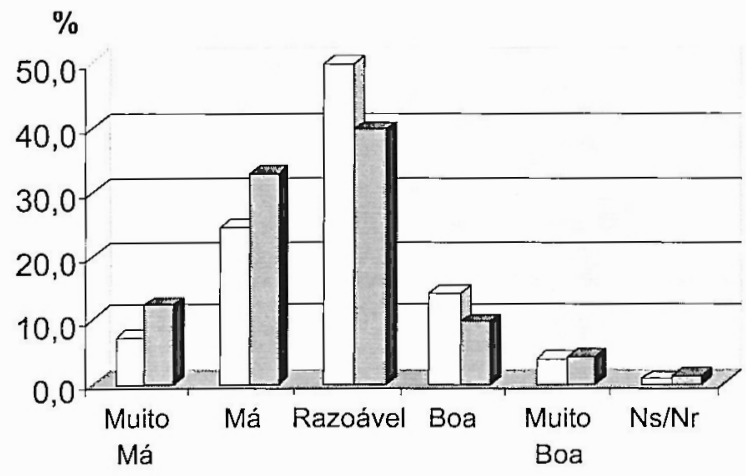

ambiente má $(41,7 \%)$, em segundo lugar referem razoável $(37,5 \%)$ e por último, com uma percentagem considerável uma qualidade do ambiente muito má $(20,8 \%)$. Embora com valores baixos, a percentagem de respostas a favor de uma qualidade do ambiente boa encontra-se nos indivíduos menos instruídos. Segundo a profissão, é nas categorias referentes aos quadros superiores que se encontra a maior percentagem de respostas a favor de uma qualidade do ambiente muito má $(15,8 \%)$, os reformados $(42,9 \%)$ e os desempregados $(41,7 \%)$ indicam em primeiro lugar uma qualidade do ambiente má e para os restantes a qualidade do ambiente é maioritariamente razoável. Os estudantes indicam já alguma preferência por uma qualidade do ambiente boa para o seu concelho $(16,3 \%)$, mas são os operários aqueles que maior percentagem apresentam nesta opção, com $21,6 \%$.

$\mathrm{Na}$ oposição rural/urbano, os inquiridos que vivem na cidade consideram que a qualidade do ambiente no concelho é razoável $(39,7 \%)$ - má $(32,9 \%)$ muito má $(12,3 \%)$, enquanto que os que vivem no meio rural consideram que a qualidade do ambiente no concelho é razoável $(49,6 \%)$ - má $(24,4 \%)$ e boa para $14,2 \%$. Comparativamente, os urbanos têm maior percentagem nas respostas muito má e má, enquanto que os rurais tem maior número de resposta nas opções razoável e boa (ver Fig. 6).

Quando particularizamos e questionamos este grupo de indivíduos sobre o modo como consideram a qualidade do ambiente na sua freguesia verificamos que as respostas vão, maioritariamente, no sentido de uma qualidade razoável $(35,5 \%)$ a boa $(26,0 \%)$, apenas $18,5 \%$ consideram má a qualidade do ambiente da sua freguesia. Se ao nível do concelho a tendência era essencialmente negativa, ao nível da freguesia essa tendência inverte-se verificando-se uma valorização das opções: qualidade boa e qualidade muito boa. A percepção da qualidade ambiental na proximidade do local de residência, parece agradar mais que aquela que se percepciona para o concelho.
Fig. 6 - Qualidade do ambiente no concelho. 
Ao analisarmos a qualidade do ambiente na freguesia segundo o sexo, apenas a registar que os homens consideram essa qualidade boa e as mulheres consideram-na razoável e muito boa. Por idades, constata-se que na classe dos mais jovens a qualidade do ambiente acompanha uma tendência positiva (razoável, boa e muito boa), enquanto que a partir dos 50 anos aumenta o número de respostas a favor de uma qualidade má.

Quanto à escolaridade, a tendência é igualmente para privilegiar uma qualidade do ambiente razoável a boa, excepção feita aos inquiridos com o ensino superior que, para a sua freguesia, indicam igual percentagem de respostas nas opções razoável e má $(41,7 \%)$ e com uma percentagem significativa para uma qualidade do ambiente muito má (12,5\%). São os indivíduos pertencentes aos níveis de instrução mais baixosque valorizam as escolhas de uma qualidade de ambiente boa para a sua freguesia.

É nas profissões correspondentes a quadros superiores, nos desempregados e nos reformados que vamos encontrar os maiores valores para uma qualidade do ambiente má a muito má. Sendo considerada preferencialmente uma qualidade razoável para a freguesia, as domésticas e os estudantes indicam como primeira opção uma qualidade boa, denotando uma tendência positiva na qualidade do ambiente da freguesia que vai ser "engrossada" pelas opções dos operários e dos indivíduos pertencentes aos serviços, que referem uma qualidade do ambiente muito boa para a sua freguesia.

Os rurais consideram boa $(33,9 \%)$ a razoável $(31,5 \%)$ a qualidade do ambiente na sua freguesia, havendo mesmo $17,3 \%$ dos inquiridos que a consideram muito boa. Os urbanos consideram que a qualidade do ambiente na sua freguesia é razoável $(42,5 \%)$ a má $(30,1 \%)$. Comparativamente, a qualidade do ambiente é razoável-má-muito má para os citadinos e boa a muito boa para os rurais (Fig. 7).

Foi nosso objectivo, com este inquérito, sentir qual o grau de conhecimento da temática riscos naturais por parte dos entrevistados, saber se este assunto faz parte das suas preocupações e inquietações. Sendo este assunto desconhecido, ou não preocupante, pensámos introduzir a temática ambiental através da percepção da qualidade do ambiente do seu concelho e/ou da sua freguesia e terminar por perguntar se as preocupações com os riscos naturais devem fazer parte das estratégias de desenvolvimento para 0 concelho.

A temática dos riscos naturais é considerada importante para $47,5 \%$ dos inquiridos e muito importante para $45 \%$; do total das respostas apenas $6 \%$ consideram este assunto pouco importante. Este assuntoé importante para os homens e muito importante para as mulheres. Os mais jovens consideram este assunto muito importante $(48,4 \%)$ e podemos dizer que o grau de importância vai diminuindo com a idade. Dos 24 aos 49 anos considera-se este assunto importante, embora seja nos mais idosos que esta opção tem maior representação $(64,7 \%)$. Com a escolaridade aumenta a importância atribuída a este assunto e é para os menos instruídos que este assunto é pouco importante, ao nível da profissão os indivíduos pertencentes aos quadros superiores, os serviços e os operários consideram este assunto muito importante, enquanto ele é importante para os desempregados, as domésticas, os estudantes e os reformados. Para os indivíduos que vivem na cidade este assunto é muito importante enquanto que os rurais o consideram, apenas, importante. De constatar, todavia, que há uma maior percentagem de inquiridos urbanos que considera este assunto pouco importante.

Terão eles já consciência daquilo que se passa em Lamaçães?

A expansão urbanística para o vale de Lamaçães verificou-se, sobretudo a partir de 1991, como consequência de uma das principais estratégias de desenvolvimento assumidas para a cidade de Braga, ao ponto da autarquia tentar avançar com o Plano de Ordenamento Urbanístico do Vale de Lamaçães, da autoria do arquitecto Mário Abreu, onde se previa a construção de 8100 fogos que albergariam mais de
Fig. 7 - Qualidade do ambiente na freguesia.

$$
\%
$$

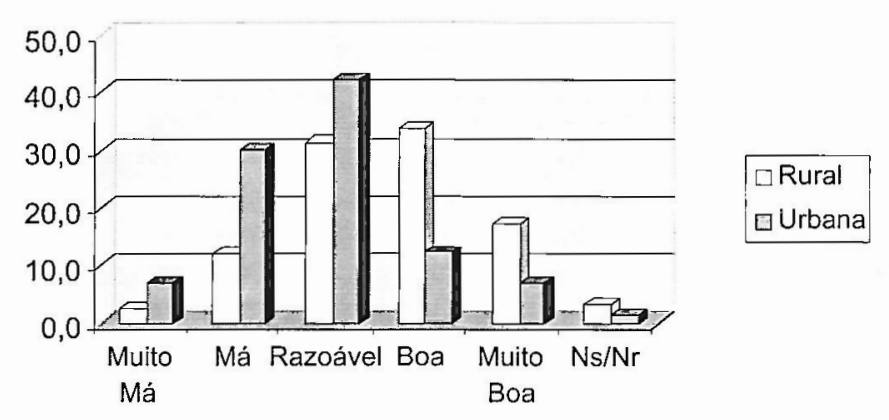


34 mil pessoas (Jornal PÚBLICO, 1991, p. 46). Apesar deste plano não ter sido aprovado funcionava já como instrumento de gestão urbanística. A construção que começou a ser fejta neste local motivou duras críticas pela consequente ocupação de solos de especial aptidão agrícola - área desafectada à Reserva Agrícola Nacional (RAN) e de zonas de relevante interesse paisagístico, nomeadamente, para as vistas do Bom-Jesus.

Com a elaboração do Plano Director Municipal, em 1993, definem-se novas estratégias para o concelho que apostam num novo ciclo de desenvolvimento: crescer com qualidade, afirmação feita pelo vereador responsável pela Divisão de Planeamento e Urbanismo da Câmara Municipal, em entrevista ao Jornal Público de 1 de Julho de 1993. Neste novo contexto de promoção da cidade, em termos de melhor qualidade de vida, o nascimento de uma nova cidade no vale de Lamaçães volta a ser a grande aposta do PDM. Se até aos anos 70 estava condicionada a construção a sul da rodovia do Bom Jesus, pelo facto do vale de Lamaçães ser considerado zona de protecção para as vistas do Bom Jesus, este eixo rodoviário constituirse-á como um separador entre aquilo que o PDM designa como "a cidade consolidada" e "a nova cidade a construir a sul" (Jornal PÚBLICO, 1993, p. 50).

Em 21 de Julho de 2000 é aprovado, em Assembleia Municipal, o novo PDM de Braga. Todavia, desde 1993 até hoje, o Vale de Lamaçães continua sem um Plano de Urbanização que ponha cobro a uma gestão urbanística que promove uma construção desenfreada em detrimento da salvaguarda e preservação de valores patrimoniais, arquitectónicos e naturais existentes nesse espaço.

A imagem que podemos reter desta nova zona da cidade de Braga, com cerca de 280 hectares, é a de forte especulação imobiliária, de elevada densidade demográfica e de construção na área de inundação do rio Este (que se encontra canalizado) e com graves problemas de humidade, devido à dificuldade de escoamento das águas.

Se por um lado Braga é apresentada com índices elevados de qualidade de vida, especialmente pela oferta que apresenta em termos de cultura e lazer, em termos ambientais, Braga tem que repensar a sua imagem. O caos urbanístico que se verifica em Lamaçães não se coaduna com os padrões de qualidade ambiental e de vida que se pretendem para uma cidade que se promove como de sucesso.

\section{Considerações finais}

Da impossibilidade em concluir um estudo que agora se iniciou apenas se apontam algumas considerações mais importantes.

O que nos moveu foi a tentativa de avaliação do nível de conhecimento que a população inquirida tem doriscoe, também, de que modo são percepcionados os riscos naturais por essa mesma população, em suma, avaliar da sensibilidade ou da sensibilização deste grupo de indivíduos para a importância dos riscos naturais em matéria de ordenamento do território.

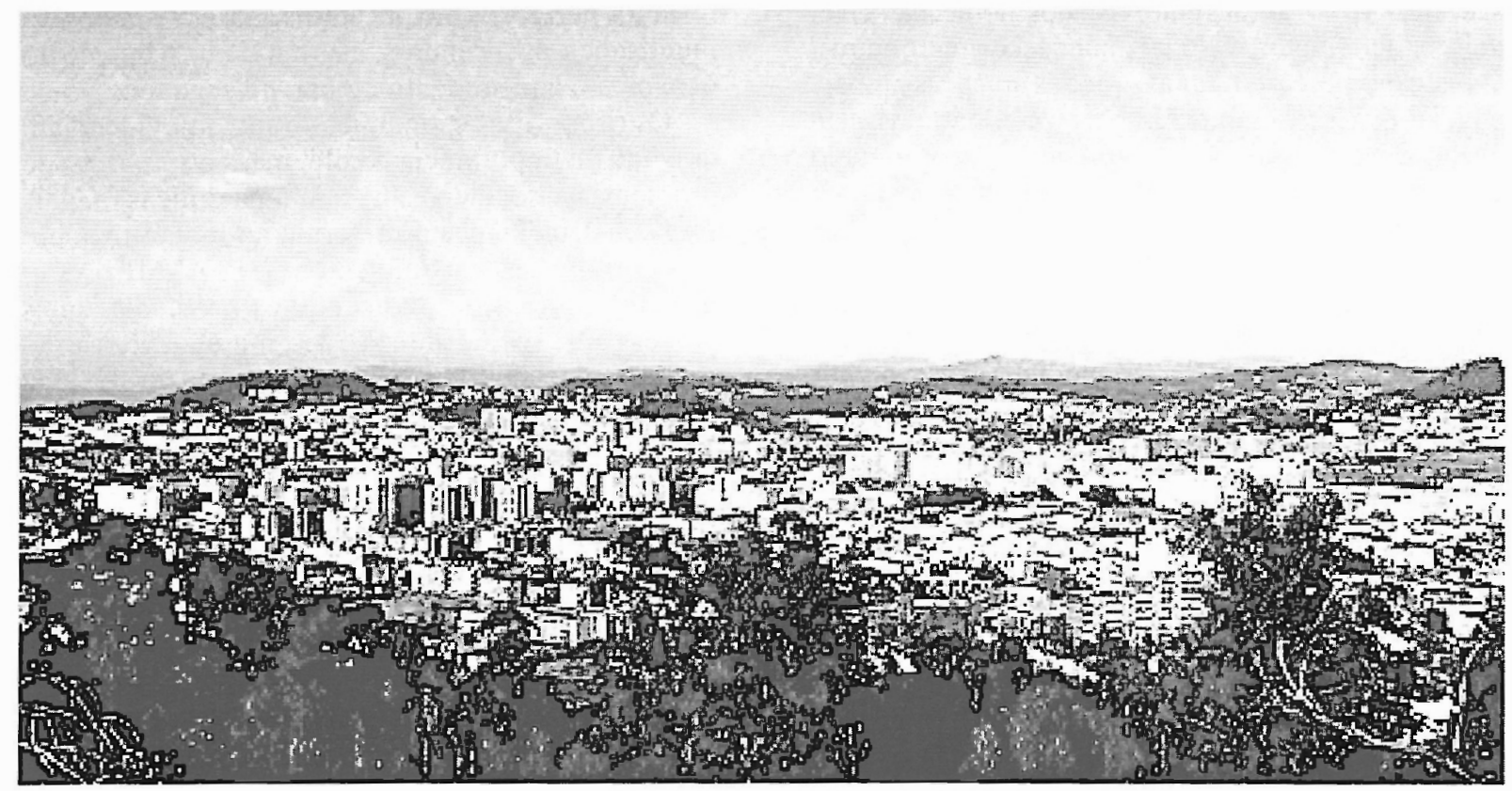

Foto 1 - Aspecto geral do Vale de Lamaçães, visto do Picoto. 
A noção de risco é de difícil definição para a maioria dos entrevistados, sendo quase sempre confundida com a de perigo. Para F. REBELO (1999, p. 8) o risco "entendido como a possibilidade de um determinado facto ocorrer trazendo danos a pessoas ou bens" associa-se à noção de vulnerabilidade. Já L. FAUGĖRES (1990, p. 92) nos diz que "o risco só existe na medida em que, através das suas manifestações, afecta as populações". Deste modo, a gravidade ou a importância do perigo potencial ao qual as pessoas estão expostas são determinadas pela intensidade dos seus impactes ecológicos, económicos e humanos, estando a sua percepção condicionada pela expressão desses mesmos impactes.

Se procurarmos atribuir uma importância aos perigos aos quais os inquiridos se consideram mais expostos, constatamos que a tendência vai no sentido de valorizar a saúde, em especial as doenças mais graves e/ou contagiosas como o cancro e a sida, e a segurança, ou melhor, a falta dela, através da referência à violência, aos assaltos, à criminalidade. A exposição aos riscos tecnológicos é considerada, também, bastante importante, quer em termos de acidentes de trabalho, quer em termos de confronto com velocidade e densidades de tráfego rodoviário crescentes. A importância atribuída à exposição aos riscos naturais embora baixa $(16,8 \%)$ é sintomática de alguma preocupação, já que de forma espontânea e sem saberem tratar-se de um questionário sobre riscos naturais, os inquiridos apontam problemas ambientais, se bem que globais, como a destruição do buraco do ozono, a poluição em termos genéricos, a contaminação das águas, as catástrofes naturais e "os perigos da natureza", como são referidos por alguns entrevistados, nomeadamente, vulcões, terramotos, ciclones, inundações, entre outros. O facto de parecerem ser as grandes ameaças globais aquelas que inquietam mais, em termos naturais, este grupo de cidadãos pode explicar-se, talvez, pelo papel que os meios de comunicação desempenham na "fabricação" de opinião pública. Como refere Jacqueline DENIS-LEMPEREUR (2000, p. 110) "a forte mediatização de um risco aumenta consideravelmente o sentimento do perigo que ele representa" ao passo que se forem pouco mediatizados, são por vezes substimados pela população. "Movidos por vezes pelo interesse mórbido do público, os media são às vezes mais ávidos de sensionalismo do que de verdade. A simplificação excessiva, que leva à destruição de uma mensagem, do mesmo modo que a dramatização e as audaciosas extrapolações que têm tendência a amplificar ou a distorcer a realidade, contribuem para deformar a percepção do risco no espirito do público" (idem). Talvez a mudança de escala do global para o nacional e regional tivesse maior expressão se este inquérito tivesse sido realizado em Dezembro de 2000 e Janeiro de 2001, após as grandes cheias e os imponentes movimentos de terras, verificados um pouco por todo o nosso país.

Ao tentarmos identificar os inquiridos que consideram estar mais expostos aos riscos naturais, encontramos as mulheres, os mais jovens e os mais instruídos, aqueles que exercem profissões mais qualificadas, os estudantes e, ainda, os que vivem na cidade.

A consciência da exposição a determinados riscos desencadeia nas pessoas crescentes sentimentos de inquietação e medo. No presente caso, as grandes ameaças vêm, todavia, do campo social: a sida, as doenças contagiosas, a droga, a violência, a criminalidade são os principais responsáveis pela insegurança, pelo sofrimento e pela morte que tanta angústia causa a estes entrevistados. Não obstante, grande parte dos medos evidenciados apresentam uma dimensão pessoal, seja com a realização profissional (o medo de falhar é enorme!), seja pelo grau de incerteza que o futuro apresenta.

Do conjunto das principais ameaças sentidas directamente pelos entrevistados e indicadas espontaneamente, as ameaças naturais são aquelas que mais baixo grau de preocupação revelam. Todavia, quando se pretende dos entrevistados uma seriação em termos de grau de importância atribuída, especificamente, aos riscos naturais, aos riscos tecnológicos e aos riscos económicos e sociais, a tendência altera-se. Os riscos tecnológicos revelam-se os mais importantes, os mais temidos, seguidos dos riscos naturais, o que deixa perspectivar uma forte preocupação ambiental, como se pode evidenciar pelos exemplos dados para cada tipo de risco: a poluição da água e do ar, o perigo nuclear, os resíduos perigosos, no primeiro caso, e os sismos, as inundações, os incêndios, mas também "o buraco do ozono" e o aquecimento global, no segundo.

Os riscos ditos económicos e sociais evidenciam um grau de importância médio, mas agora, o tipo de problemas associados abarcam uma dimensão mais vasta. À semelhança do referido no inquérito sobre "Os portugueses e o ambiente" (J. F. ALMEIDA et al., 2000, p. 53), no momento, os problemas mais graves para a sociedade são o desemprego, a exclusão social (fome pobreza e miséria), o custo de vida (baixos salários, ínfimas reformas, altos preços) com risco de endividamento, a droga e a criminalidade.

Do exposto, podemos afirmar que a degradação do ambiente, vista quase sempre à escala do mundo, entrou já no domínio das preocupações, especialmente, dos mais jovens e dos mais escolarizados, concerteza os mais informados sobre as questões ambientais ${ }^{1}$,

I O artigo "Ensino da Geografia e Riscos Naturais. Reflexões a propósito de um mapa de riscos naturais do Vale de Coselhas (Coimbra)" da autoria de L. CUNHA e R. ROCHA (1997) é umbom exemplodo interesse pedagógico que a temática dos riscos naturais pode ter ao nível do Ensino Secundário, contribuíndo para fundamentare formar uma consciencialização ambiental mais enriquecedora. 
como de resto é indicado no inquérito nacional atrás referido: "se a idade é uma variável importante para explicar a preocupação ambiental, em parte porque os processos de socialização mais recentes passaram a integrar o tema do ambiente - seja no campo educativo, seja no campo mediático - a escolaridade, enquanto elemento essencial do capital cultural, parece também indissociável da inquietação ambiental." (idem, p. 39)

Restringindo o nosso campo de visão à escala do concelho, a imagem que registamos dos riscos naturais é a dos incêndios florestais, dos ventos fortes e das inundações, embora os entrevistados tenham deles uma percepção de importância média a fraca.

Em termos de qualidade ambiental, inquéritos realizados por várias instituições ${ }^{2}$ mostram que as apreciações sobre o estado do ambiente são tanto mais positivas quanto nos interessamos pelo ambiente próximo, logo, melhor conhecido, ou seja, a percepção do ambiente tem tendência a agravar-se à medida que aumentamos a distância. De resto, é o que se passa no nosso estudo em que a percepção ambiental da freguesia é mais satisfatória que aquela que é evidenciada para o concelho. Contudo, os entrevistados que vivem na cidade são igualmente críticos quanto à qualidade do ambiente do concelho e da sua freguesia. O sentimento de desqualificação ambiental do local de residência manifestado por este grupo de pessoas poderá encontrar justificação nos principais problemas que afectam hoje as grandes cidades e aos quais Braga não escapa: o trânsito, a poluição, a construção desenfreada sem qualidade, de que Lamaçães é um bom exemplo, em suma, o desordenamento urbano. temática dos riscos naturais (Tabela II) revelam já uma preocupação crescente com os fenómenos da natureza que, na opinião de alguns inquiridos, podem acontecer a qualquer momento sem estarmos à espera. Assim, é necessária uma política de prevenção e de sensibilização das pessoas, o que justifica uma importância crescente do acesso à informação.

Ou seja, a própria população tem já uma forte consciência da necessidade da inclusão daquilo a que podemos chamar uma "cultura do risco" nas políticas de planeamento local e particularmente nos planos directores municipais e nos planos de urbanismo. Dito de outra forma, a percepção do risco ambiental passa a ser também um importante instrumento de planeamento e ordenamento, pelo menos à escala municipal. Claro que os custos inerentes a uma cartografia de riscos naturais, necessariamente baseada em cartografia geológica e geomorfológica de pormenor, leva muitas vezes os autarcas a esquecer este instrumento de planeamento. Mas, não será este esquecimento o modo mais simples de evitar uma classificação rigorosa dos solos para usos urbanísticos? Assim, se deixa o espaço aberto ao crescimento desordenado das novas áreas de expansão urbana, independentemente do valor ecológico ou agrícola dos solos, da sua localização em vertentes de fortes declives ou nos leitos de cheia, ao sabor da especulação imobiliária e do lucro de uns poucos, mas com inevitáveis custos económicos e sociais para todos, quando se trata de dotar de infra-estruturas capazes estas novas urbanizações ou quando se trata de realizar intervenções para mitigar os riscos naturais que elas envolvem.

\begin{tabular}{|l|c|}
\hline \multicolumn{1}{|c|}{ Motivos } & No $^{0}$ Respostas \\
\hline Prevenção & 67 \\
Informação & 13 \\
& \\
Devido à má urbanização/mau planeamento & 29 \\
Preservação da Natureza & 23 \\
Para o bem-estar das populações & 23 \\
Qualidade ambiental/poluição urbana & 3 \\
\hline
\end{tabular}

Tabela II - Riscos Naturais versus Estratégias de Desenvolvimento
Será também por estes motivos que a maioria dos inquiridos manifestou interesse em que os riscos naturais fossem contemplados aquando da definição das estratégias de desenvolvimento para o concelho. Se bem que, com algumas confusões, as justificações avançadas pelos inquiridos sobre a importância da

2 Os inquéritos realizados pelo CREDOC sobre as "condiçóes de vida e aspiraçōes dos franceses" citado por J. Denis-Lempereur (2000) serviram, também, de referência à equipa que realizou o inquérito sobre "Os portugueses e o ambiente" (Observa, 2000).

\section{Bibliografia}

ALMEIDA COSTA, J.; SAMPAIO E MELO (1994)-Dicionário da Lingua Portuguesa. $7^{\mathrm{a}}$ Edição. Porto Editora.

ALMEIDA, J. FERREIRA (Org.) (2000) - Os portugueses e o ambiente. I Inquérito Nacional às representaçôes e práticas dos portugueses sobre o ambiente. Celta, Observa.

BAILLY, A.(1977)-Laperception de l'espace urbain. Les concepts, les méthodes d'etude, leur utilisation dans la recherche urbanistique. Centre de Recherche d'Urbanisme, Paris. 
BAILLY, A. (1989) - "L'imaginaire spacial. Plaidoyer pour la géographie de répresentations". Espace et Temps, Paris, $40-41$, p. $53-58$.

CHARVÉRIAT, C. (2000) - "Les risques liés aux catastrophes naturelles: le cas de l'Amérique Latine et des Caraïbes". In Revue International et Stratégique, 39 - Dossier: "Sécurité et Environnement: Le risque au coeur des politiques". Automne 2000.IISSEN. Québec. (p. 84-92).

CUNHA, L.; JACINTO, R. (1992) - "A questão ambiental e a sua percepção em Portugal". Actas VI Colóquio Ibérico de Geografia. Porto, p. 1061-1074.

CUNHA, L; ROCHA, R. (1997) - "Ensino da Geografia e Riscos Naturais. Reflexões a propósito de um mapa de riscos naturais do Vale de Coselhas (Coimbra)". Cadernos de Geografia, $n^{\circ} 16$, Coimbra, p. 25-38.

CUTTER, S. L. (1993) - Living with risk. The geography of technological hazards. Edward Arnold. 214 p.

DENIS-LEMPEREUR, D. (2000) - "Opinion publique et sécurité environnementale". In La Revue International et Stratégique, 39 - Dossier: "Sécurité et Environnement: Le risque au coeur des politiques". Automne 2000.IISSEN. Québec. (p. 102-110)

FAUGËES, L. (1990) - "Les Risques Naturels". Bull. Assoc.Géogr. Franç., Paris, p. 89-98.
Jornal PÚBLICO, Domingo, 10 Março de 1991, Local.

Jornal PÚBLICO, Quinta-feira, I Julho de 1993, Local.

KERVERN, G-Y, RUBISE, P. (1991) - L'archipel du danger. Introduction aux cindyniques. CPE. Ed. Economica, Paris. $444 \mathrm{p}$.

LIMA, M. L.; FAİSCA, L.M. (1992) - Contribuição das Ciências Sociais para o estudo do impactes das cheias. LNEC, ITECS 13, Lisboa, 1992, 82 p.

PAINCHAUD, P. (2000) - "La sécurité environnementale: concept et perspectives". In La Revue International et Stratégique, 39 - Dossier: "Sécurité et Environnement: Le risque au coeur des politiques”. Automne 2000. IISSEN. Québec. (p. 61-66).

REBELO, F. (1999) - "A Teoria do Risco analisada sob uma perspectiva geográfica". Cadernos de Geografia, IEG, FLUC, Coimbra, 18, p. 3-13.

REBELO, F. (2001) - Riscos naturais e acção antrópica. Imprensa da Universidade de Coimbra, Coimbra, 274 p.

TELES, V. (2001) - “Sobre a consciencialização do risco. A propósito da localização de edifícios escolares". Actas II Colóquio de Geografia de Coimbra, Maio 1999. № Especial de Cadernos de Geografia, Coimbra, p. 155-163. 